\title{
Power Discourse: An Analysis of Zulfikar Ghose Collection of Poems in perspective of Michel Foucault's Bio Power Theory
}

\author{
Maryam Fiaz ${ }^{1}$, Hina Rafique ${ }^{2}$, Farhana Tabassum ${ }^{3}$ \\ ${ }^{1}$ BS English, Punjab University, Pakistan \\ ${ }^{2}$ Assistant Profes sor of English, Govt.P.G.College (W) Satellite Town. Gujranwala, Pakistan \\ ${ }^{3}$ Senior Lecturer, University of Lahore, Lahore.Pakistan
}

\begin{abstract}
The present research study is an analysis of Zulfikar Ghose' poetry who is Pakistani poet writing in English. The researcher aims at analyzing his collection of poetry 50 Poems: Selected and New Poems in the light of Michael Foucault's Biopower theory. Ghose' collections of poetry are embedded with the elements of Diaspora, exile, alienation, loneliness, strangeness and search as well as quest for his own identity and cultural values. The study has investigated the language phenomenon of his poems under the framework of Foucault's theory. Hence, few of the poems from the collection have been analyzed from the perspective of notion of power and biopower to argue the notion that Ghose poetry talks about power and negotiates power ideology. The colonial burden of the subjects in his poetry, the cultural erosion and identity crisis and supremacy of language has been pointed out under the canopy of power matrix. The study positively contributed to Pakistani literature and modern literary theory.
\end{abstract}

Keywords- Power, Biopower, Diaspora and Identity crisis, Pakistani Literature.

\section{INTRODUCTION}

The researcher in this study aims at analyzing Ghose collection of poetry 50 Poems: Selected and New Poems in the light of Biopower theory of Michael Foucault. The research study investigates the language and style of Ghose' poetry contributing to power ideology. Most of the works of Zulfikar Ghose is an attempt to find identity and homeland. His works are tangled with the themes of Diaspora, memory and homelessness. He has used powerful terms and language in his poetry to convey his messages. His poems are based upon powerful meaning with powerful discourse. So, by applying the idea of governmentality or biopower upon his poetry, the researcher has negotiated the power domain and underlying meaning of his poetry. Michael Foucault was a French philosopher and historian, he draws a relationship between power and knowledge. He said that Biopower is having power over other bodies, as Foucault quotes in his book History of Sexuality about this: "an explosion of numerous and diverse techniques for achieving the subjugations of bodies and the control of populations"(140).

Foucault further elaborates this concept by introducing the terms of discourse, power, knowledge, discipline, Governmentality or Biopower. In Discourse he defines the idea of reality, social world, people, and the things that happen in this world through the phenomenon of Discourse. It is simply a way or medium of expressing reality and truth. He describes the relationship between Power and Knowledge by saying that knowledge is an exercise of power on the other hand power is the function of knowledge. While Discipline is a mechanism of power that rules and regulates the mind and behavior of society. He said that governmentality does not mean the art of ruling in state instead it deals with governing upon persons, thoughts and at a micro level with any abstract idea. So, biopower gives the idea of management, understand policies and work upon them.

1.1 Research Methodology:

This study is descriptive and qualitative research study. Besides, Michel Foucault's concept of Biopower theory has been taken as a theoretical framework of this research work. Ghose selected poems have been analyzed in light of his power notion. Furthermore, it is textual analysis and is interpretive in nature.

1.2 Significance of Research Study

This research study is a fruitful addition in field of Pakistan literature, South Asian literature and modern 
literary theory and this research study would be helpful for the students and researchers who will select Ghose's poetry for their research area in the future. This is textual analysis and study is interpretive in nature.

1.3:Theoretical background: Michel Foucault's Concept of Biopower

Michel Foucault was a French philosopher and historian. He has had strong influence not only in philosophy but also in a wide range of humanistic and social scientific disciplines. His best known works are Discipline and Punish(1991)and The History of Sexuality(1978). Michel Foucault has influenced the study of politics. This influence has mainly been analyzed through his concepts of; Governmentality and Biopower.

Michel Foucault has been greatly influential in promoting understanding of the concept of power. His theory of Biopower has received much popularity in recent years. Biopower, a term coined by Michel Foucault, literally means to have power over others. It is actually "an explosion of numerous and diverse techniques for achieving the subjugation of bodies and the control of populations" (140). Foucault contrasts his concept of Biopower with traditional mode of power which was based on the threat of death from a sovereign. Biopower emphasizes the protection of life rather than the threat of death. It focuses upon the regulation of the body and the production of other technologies of power. Foucault argues that "power is everywhere diffused and embodied in discourse, knowledge and regimes of truth"(n.p).

The fundamental idea emerging from all his works is that the privileged place to observe the power in action is the relation between the individual and the society, especially its institutions. While presenting analysis of power, he elaborates that how various institutions exert their power on groups and individuals, and how the latter affirm their own identity by resisting to the effects of power.

In opposition to the classic understanding of power Foucault defines power as positive rather than a negative force. It is limitative and akin to censorship. The most significant feature of Foucault's ideology is his stress on the productive nature of power's modern exercise. His main aim was to turn a negative concept upside down and points out the production of concepts, ideas, and the structures of institutions by the mere exercise of power in its modern forms. Foucault argues in this regard:
We must cease once and for all to describe the effects of power in negative terms: it 'excludes', it 'represses', it 'censors', it 'abstracts', it 'masks', it 'conceals'. In fact power produces; it produces reality; it produces domains of objects and rituals of truth. The individual and the knowledge that may be gained of him belong to this production (194).

To reinforce this idea, John Gaventa states about Foucault in Power after Lukes: A Review of the Literature as:

"His work marks a radical departure from previous modes of conceiving power and cannot be easily integrated with previous ideas, as power is diffused rather than concentrated, embodied and enacted rather than possessed, discursive rather than purely coercive, and constitutes agents rather than being deployed by them" (01).

Foucault thinks that it is wrong to consider power as something that the institutions possess and use oppressively against individuals and groups. He tries to move the analysis one step beyond viewing power as the plain oppression of the powerless by the powerful. He talks about the positive aspect of possessing power. John Gaventa remarks in this context:"Foucault is one of the few writers on power who recognize that power is not just a negative, coercive or repressive thing that forces us to do things against our wishes, but can also be a necessary, productive and positive force in society" $(02)$

Furthermore, his theory aims to examine how power operates in day to day interactions between people and institutions. In the first volume of The History of Sexuality he argues that we must overcome the idea that power is oppression, because - even in their most radical form - oppressive measures are not just repression and censorship, but they are also productive, causing new behaviors to emerge.

Foucault is concerned less with the oppressive aspect of power. He is more concerned with the resistance of those the power is exerted upon. Foucault proposes that power relations dissipate through all relational structures of the society. This enables him to build a model of the everyday manners in which power is exerted and contested. It is an analysis which centers on the human individual as an active subject, not as a simple object for the power.

Usually, power is understood as the capacity of an agent to impose his will over the will of the powerless, or the ability to force them to do things they do not wish to 
do. In this sense, power is understood as possession. It is taken as something owned by those in power. But in Foucault's opinion, power is not something that can be owned. It is rather something that acts and manifests itself in a certain way. It is more a strategy than a possession. Foucault further states;"Power must be analyzed as something which circulates, or as something which only functions in the form of a chain ... Power is employed and exercised through a netlike organization . . . Individuals are the vehicles of power, not its points of application"( 98).

This way of understanding power has two key features. First is that power is a system, a network of relations encompassing the whole society, rather than a relation between the oppressed and the oppressor. Second is that individuals are not just the objects of power, but they are the locus where the power and the resistance to it are exerted. Foucault argues in The History of Sexuality that:"Power is coextensive with resistance, it is productive - i.e., it causes positive effects -, and it is ubiquitous i.e., it can be found in any type of relation between the members of society, being a possibility condition for any relation"(142).

Considering power as strategy and not as possession means to think of it as something that has to be exerted and not something that can simply be acquired. It is not restricted solely in certain institutions or individuals. It is rather a set of relations dispersed throughout society. Foucault argues that;

"I am not referring to Power with a capital P, dominating and imposing its rationality upon the totality of the social body. In fact, there are power relations. They are multiple; they have different forms, they can be in play in family relations, or within an institution, or an administration" (38)

Foucault thinks that power must be understood differently than repression, which simply forces individuals to obey. He further states that power is "coextensive with resistance; productive, producing positive effects; ubiquitous, being found in every kind of relationship, as a condition of the possibility of any kind of relationship"(38). Foucault states further that "where there is power there is resistance"(38). Resistance on the part of oppressors means whenever oppressors are oppressed they fight back to challenge power exercised on them. This means that the power relations between individuals cannot be reduced only to master-slave or oppressor-victim relations. They are productive relations because they imply resistance without which no power relation can be conceived: "where is power, there is always someone who resists it"(Foucault n. p).

For Foucault, the state is not mainly something that owns power. But it is rather something which builds a system of relations between individuals so that the political system works. In Discipline and Punish: The Birth of the Prison, he reviews the ways in which power was exerted in various stages of European history. He shows how the monarchic power system was replaced by the democratic one. He uses the punishment imagery in an expressive way.

Foucault argues that "power produces; it produces reality; it produces domains of objects and rituals of truth"(194). The institutions use various types of power enforcement with specific mechanisms and techniques. Foucault shows how the hospital, the clinic, the prison and the university share some of these disciplinary techniques and practices. Discipline is a concern for control. It is internalized by every individual, referring to temporal bench-marks, bodily posture and functions, sublimation of wishes and immediate emotions.

In case of political power, Foucault studies power relations related to government questioning as who can and should govern. Who is to be governed and how should we devise the appropriate strategies to govern. Fundamentally, he thinks that political power relations are doomed to fail in reaching their goals. Most frequently they do not reach their final goal of absolute domination. Foucault further argues that relations between parents and children, between lovers, between employers and employees - all are power relations. In every human interaction, power is subject to negotiation. Each individual has his place in the hierarchy no matter how flexible it would be.

Foucault analyses the relations between individuals and society without assuming that the individual is powerless compared to institutions, groups or the state. He doesn't minimize the restrictions imposed on individuals, but thinks that power is not concentrated, but diffusing throughout the whole society. This shows that the concept of power is taken as a volatile, an unstable element, which can always be contested. So power relations must be permanently renewed and reaffirmed. 


\section{DISCUSSION: ZULFIQAR GHOOSE POETRY AS POWER DISCOURSE}

This section of the paper aims at the analysis of Zulfiqar Ghose 's selected poems where the concept of power is dominated. His poetry presents the post colonial impact and the relation between the colonizer and the colonized. This section aims at the discussion of few of his poems from selected text 50 Poems: Selected and New Poems in perspective ofMichel Foucault's concept of biopower. Biopower, a term coined by Michel Foucault, literally means to have power over others. It is actually "an explosion of numerous and diverse techniques for achieving the subjugation of bodies and the control of populations" (140). Out of several terms introduced by him, the notion of bio power and power will be taken to analyze his poetry. The word biopower gives the idea of management, understanding policies and work upon them.

A memory of Asia is one of the most important poem by Ghose which can also be analyzed in context of power notion. The poem presents a scene of Indian culture steeped into Indian mythology. here the poet has mentioned Ganpati ,the Hindu God, which according to me is the object of power if analyzed in the present context.

Pot bellied Ganpati, the Hindu God, garlanded with Marigolds and jasmine and with his elephant head painted the red they usedfor post boxes, small brass hanging from, the ceiling to his shoulders and at his feet, brass trays heaped with mangoes, papayas and jackfruit.(37)

Ganpati is the Hindu god with elephant trunk in Indian mythology but here in the festival he was being carried away and being worshipped. Different fruits (mangoes, papayas and jackfruit )and flowers (marigolds and jasmine) are being offered to him and have been placed in his honour. Bells are there to ring. In Indian mythology, there are different Gods, God of knowledge, God of festivity etc. Similarly in Greek mythology also, there are different Gods: God of love, God of beauty, God of wine etc. These gods are actually harbingers of power. It means they have power to control that domain which has been given to them. People worship them because of the powers they possess. Ganpati is also being worshipped because of his power. Power is not only negative it is also positive.

Foucault talks about the positive aspect of possessing power. John Gaventa that "Foucault is one of the few writers on power who recognize that power is not just a negative, coercive or repressive thing that forces us to do things against our wishes, but can also be a necessary, productive and positive force in society"(02).

One chooses a language is another important poem to discuss in case of power. In this poem, the poet has talked about the superiority of a language: positive and negative power.The poet has co related memory with language and talked about the importance of language in memory. He says that when reading alphabet $\mathrm{A}$ it is not just a but $\mathrm{t}$ also brings to mind a for apple which we should to read in our childhood.

The English alphbet dangled it's $A$

for apple when I was eight in Bombay

I shuttered and chewed almonds for a cure my tongue, rejecting a vernacular,

for a new language, resisted utterance.

alone, I imitated the accents of English soldiers', their pitch and their tone.

they were the tongues to my mouth's microphone.(35)

In these lines, Ghose has talked about the idea I have mentioned above but there is another fact which has been mentioned that is the colonizing impact of English language. English is the language of colonizers, this fact strengthen the idea of power given by Foucault. We need to go into the history of this notion to talk about English as a power language. In sub-continent, before partition, when colonizers came to have political and economic control of subcontinent, they tried to implement their own language on the masses. The 1867 Urdu Hindi dispute was also the result of this language power game when it was declared that Hindi would be the official language of the state. It was a step to attack on the Muslim identity through language. Language bespeaks of your identity. But Muslims stood against that act. As Foucault states further that "where there is power there is resistance"( Foucault 38 ).

English was considered oncethe language of power and supremacy which was the language of Raj once but now it has emerged as a language of power with positive impact: a lingua franca. Since then nations have been striving hard to learn it, and to flourish it. A powerful nation exploits underdeveloped nations through its language. As Foucault says that power operates through different sources and channels, so colonizers also take their language as a tool to empower other nations. In the above written lines, the poet has talked about that phenomenon when he said that he was trying to imitate 
the accent of English solider. It was probably the same time of partition and political authority which he was facing when he was of eight years old only. So language as a power phonemenon appears in this poem.

Another fact which has been pointed out by the poet in the poem is when he states "People go elsewhere learn the strange tongue to make a new living"(35). Here again the colonizing impact of language of the country can be noted where the people migrated to. In order to make their living possible there, they have to learn that language which becomes the language of power at that time. The researcher has presented the positive impact of second language here by taking about the dominance of the language of the time. Hence, language also fits into the idea of biopower as it appears as a system which has political understanding.

Language has such a powerful impact that sometimes we try to recall phrases and words of a particular poet and the writer, but we are unable to recall its author's name. Those words and phrases come back to our consciousness, it means they have powerful impact on our memory.

Attack on Sialkot is one of the famous poems of Ghose where this concept of power, domination and misuse of power is prominent. The poet is recalling his early days in Sialkot and his grandfather who was an epitome of cultural values and cultural heritage. He has narrated the incident of bombing in Sialkot.

Gunfire made Sialkot a kiln to fire

Pakistan's earthen-pot faith.

An arrow pointed at Sialkot(11)

The poet says that on the map an arrow was pointed at Sialkot meaning by that Sialkot is going to be the target of exploitation and power game. His grandfather is an epitome of sacredness and religious values as he used to offer prayers five times. And he was also killed in this massacre, in this game of blood and power. He states:

From the east and the southeast, from the air,

the jets converged all month on Sialkot

in a massive pilgrimage, bloodier than the annual sacrifice of goats and sheep.

Grandfather, the landmarks are falling.(11)

In the above written lines, the vocabulary is worth noticing as the words' jets' and 'blood' tell the readers that the poet has presented the destruction of the city and the mosque in result of attack on Sialkot in 1965 when a war stuck between India and Pakistan which according to him would be the downfall of Islam and its Islamic values. This war and death imagery hints towards colonizing mission of the colonizers. This poem is the fine example of the notion of power which makes it a power discourse. It presents a war between powerful and powerless where powerless are toppled down physically by the dominated ones. The poet is recalling the dominating personality of his grandfather and his association with Islamic culture. His death and colonization has been co related. Colonization which in itself is the game of power. The poet has used powerful colonizing and war imagery in the poem which supports this notion I have negotiated. The notion that power is the system can be negotiated through this concept of colonization.

The next poem is This Landscape, These people, where the poet has again talked about his childhood in India. He recalls:

My seven years in India I swarm

along the silver beaches of Bombay

pulled coconut from the sky (08)

The poet is in foreign land but he is recalling his homeland and childhood days spend there and is analyzing the situation of his country. He has presented the internal situation of India which is the hub of people belonging to different religions and races. India promotes racism based on cultural and religious differences and Ghose has acknowledges this:

India halted as suddenly as a dog

Barking, hangs out its tongue, stifles his

cry,

An epic turned into monologue of death

The rope lay still across the country

All fires were eaten, swallows were all

the swords

The horizon paled, then thickened and then blackened with crows.(09)

These lines are of prime importance in analysis of notion of power ideology. Here the writer has used the metaphor of dog for India,who stiffens his tongue, sometimes it starts barking then he stops for sometimes. The idea of internal racism strife also appears in the poem which continue to exist there. In the previous verses, he has talked about different prevailing cultures in India. There is reference to bamboos snake charmer and jugglers which represent the rural culture in Indian villages. When we analyze this poem from the power perspective as the researcher has to point out the elements of power in perspective of Foucault's concept of power, so the notion 
of exploitation is also present in this poem but the poet ahs talked about, the internal strife and disputes. In these lines, "this landscape, these people bound by their own fire/ Born here, among these people, I was a stranger"(09). Not only he has talked about his double identity but he has also shed a light on the fact that India has his own fire: fire of disputes, racism, exploitation and religious differences. Because of which it is losing its strength as these people are actually its strength but all exploitation is done on power game. Fredrick Ruban states:

This Landscape, These People is an epitome of reminiscence surfacing diasporic consciousness and reminiscence is explicated...it is one of the landscape poems of Zulfikar Ghose which has England as its one setting and India as the other. The poem has an autobiographical tome in which he realizes his state of excitement and makes distinction between his life in Indian and England. (p.40)

The next poem Remove is also a beautiful example of this power ideology which presents the partition scenario in sub-continent. What was partition after all. It was just a game of power from both sides. When one nation kills other it is on the basis of power of religion, ideology and physical strength. The poem narrates the history and literature lessons when there was mutual respect and brotherhood among people of all religions. The time came when everything dispersed. In the following lines the poet this scene presents:

Mr Iqbal has come to London to teach English

To Punjabi Sikhs and Muslims

And his pinned up in his class pictures of Gandhi and Jinnah, Nehru, and Ayub

in case the parents come to ask in Punjabi

how the kids are doing in English.(17)

In these lines the reference to all religions can be noted but in the coming verses the poet has presented partition scenario.

And the Punjab became east Punjab,

And west Punjab, and the Sikhs did not like it

And the Muslims did not like the Sikhs

Not liking it that they killed each other

Not by the hundreds nor by the thousands

But by the hundred thousands.(18)

Very beautifully, the poet has mentioned the partition of multi cultured and multinational country into two countries as Sikhs, Muslims, Hindus all were in their power circles in that country but with riots when everything fallen apart, it was on the basis of notion of power as Foucault states that "power produces; it produces reality; it produces domains of objects and rituals of truth"(194). On this power idea, every nation thought it was the most powerful and it could show its power in snatching its right form others. All this exploitation, massacre and bloodshed, according to the researcher is power based act. It is rather a set of power relations dispersed throughout society. Foucault says that:

I am not referring to power with a capital $\mathrm{P}$, dominating and imposing its rationality upon the totality of the social body. In fact, there are power relations. They are multiple; they have different forms, they can be in play in family relations, or within an institution, or an adminis tration.(38)

In light of this statement this partition act is analyzed which has started game of power and exploitation and the result of that partition has been presented by the poet beautifully:

Here then is Iqbal with the remove class of twenty Punjabis

Some Sikhs and some Muslims,

In a secondary modern school in London, all of them trying to learn English.(18)

All the characters belonging to different nations and religions present in the poem are trying to learn one language, English, which is powerful language as it is the language of colonizers, language of supremacy and dominance. All are keen to learn this powerful language for their survival in the worlds. This idea of learning English in one school promotes power ideology in Ghose poetry which he has communicated through powerful language. As Foucault states that power creates chains of relations and a system around it, the analys is of few of the poems from Ghose' poetry confirms this idea. He has shown the effect of power and the powerful on the people in the society whether that is colonizer's power or the power of language.

\section{CONCLUSION}

The researcher has selected poetry of Zulfiqar Ghose, who is one of the most important Pakistani poet writing in English, from his collection of poetry in this research study to analyze one of its aspect. The poetry of Zulfikar Ghose presents themes of exile, homelessness, survival, hope, memories and deviation from roots. Michel Foucault's concept of Biopower has been taken by the 
researcher to analyze his poetry. Foucault's concept of power is of the prime importance in that theory where he has stated that power is not only negative but it also has positive force. It comes as a chain because it continues from one person to another and gradually from top to down hierarchically and finally it steeps into the system. He said that the concept of Biopower is having power over other bodies. He postulates in his book History of Sexuality about this: "an explosion of numerous and diverse techniques for achieving the subjugations of bodies and the control of populations"(140). The terms of Discourse, Power Knowledge, Discipline, Governmentality or Biopower has been presented in this framework. He describes the relationship between power and knowledge by saying that knowledge is an exercise of power on the other hand power is the function of knowledge.

In this research study, Zulfiqar Ghose' few poems have been analyzed among which two three are about language where the concept of language as positive and negative power has been discussed here. His few poems are about partition scenario and multicultural background of India, in them partition has been taken as a game of power. An Attempt has been made to justify the research notion taken by the researcher to negotiate the power ideology propagated by Michel Foucault in language and themes of Ghose poetry. In the present research study the researcher has strengthen the concept of Ghose's poetry and his ideas by applying and critically analyzing his usage of language in the light of Foucault's Biopower Theory

\section{REFERENCES}

[1] Aardse, K. (2016). The biopolitics of electronic literature: On the writing of Mez Breeze. Digital Literary Studies , (1)1. doi:10.18113/P8dls 1159648

[2] Abbasi, M. (2015). Zulfiqar Ghose: The Lost Son of the Punjab. UK: Cambridge Scholars

[3] Publishing. ISBN (13): 978-1-4438-7546-2. Retreived from: https://www.cambridgescholars.com/download/samp le/62488Accessed on: 22 November, 2018.

[4] Abbasi, M. (2011). An Interview with Zulfiqar Ghose. Pakistaniaat: A Journal of Pakistan Studies, (3) 1, 112-119.

[5] Awan, S.F. (2013, September 3). "Unwilled Choices": The exilic perspectives on home and location in the works of ZulfiqarGhose and Mohsin Hamid, Pakistaniaat: A Journal of Pakistan Studies, (5)2, 6-21
[6] Foucault, M. (1978). The History of Sexuality. Vol. 1, New York: Pantheon Books.

[7] Gaventa, J. (2003). Foucault: Power is everywhere. Powercube. Web. Retrieved from: https://www.powercube.net/other-forms-ofpower/foucault-power-is-everywhere Accessed on: 2 Jan, 2019.

[8] Foucault, M. (1990). Politics, Philosophy and Culture: Interviews and other writings 1977-1984. Lawrence D. Kritzman (Ed.), New York: Routlage, Chapman \& Hall.

[9] Foucault, M. (1995). Discipline and Punish: The Birth of Prison. $2^{\text {nd }}$ ed. Alan Sheridan (trans.) New York: Vintage Books.

[10] Ghose, Z. (2010, January 1). 50 Poems: 30 Selected 20 New. Oxford University Press.

[11] Hashmi, A. (1992). "A Stylized Motif of Eagle Wings Woven": The Selected Poems of ZulfikarGhose. World Literature Today, 66(1), 6669. doi: $10.2307 / 40147860$

[12] Kanaganayakam, C. (1985). Paradigms of absence: The writings of Zulfikar Ghose (T). University of British Columbia. Retrieved from:https://open.library.ubc.ca/collections/ubcthese s/831/items/1.0096670 